\title{
THE NEW ZEALAND GRASSLAND ASSOCIATION AND THE PASTORAL FARMERS
}

\author{
J. A. H. INGLIS \\ Fanner, Woodville
}

\begin{abstract}
Now that the New Zealand Grassland Association has been in existence for half a century, it is some cause for celebration, hut more importantly it is a reminder that we should take stock of ourselves and ask if the Association has achieved much and, most importantly, whether there is a case for its continuing existence in current or any other form. The author, a pastoral farmer who has been actively participating in the Association's activities for over fifteen years, submits the answer to both questions is "Yes" and cndeavours to examine why.
\end{abstract}

\section{HAS THE ASSOCIATION A PURPOSE?}

FIRSTLY, we may fairly take it as a fact that grassland farming, either pure as on much hill country, or mixed with cropping, produces $70 \%$ of New Zealand's exports and is thus the chief industrial base of the nation. What is good for farming is good for the nation as a whole.

Secondly, we need hardly examine in detail whether it has been possible for scientific research to benefit the industry.

Thirdly, can research. continue to be useful, even though it may be assumed the easy work in this field has mostly been done? 'This is scarcely the place to go into detail of problems now being researched, of problems which could and should yield to research and of the scope there is for plant breeding and selection, plus discoveries of new material. Those who hear or read this year's papers, plus other current material, should be left in no doubt that great progress can and must be made in future.

Fourthly, scientists must be highly trained and often highly specialized. How are they to become motivated to do useful work? Are they to be directed from on high by one paragon or several paragons who can synthesize just what programmes are to bc undertaken? Are they as a group to decide what they should do 
while living in their proverbial ivory towers? Should the research fraternity just listen to political pressure groups who, not always with the benefit of much current scientific knowledge, periodically declaim the need for some isolated information? Or is it a good thing for some forum to exist where researchers (including directors), teachers and users of information be they farmers or farmer-servicing interests, can meet together for formal and informal discussion and interchange of ideas at the same time as knowledge is imparted? If this last alternative is accepted, as I submit it must be, then this Association has an objective and a national duty to continue and develop its activities.

\section{WHAT HAS THE ASSOCIATION ACHIEVED?}

The New Zealand Grassland Association has conducted annual conferences for fifty years and publishes its Proceedings as part of the literature. When there was a need to handle more submitted papers than could be read at regular conferences, "Part 2" Proceedings were published, but as the number of journals in New Zealand increased, Part 2 became redundant. Now it is possible a field of specialized occasional seminars may continue after the highly successful one on herbage seed production.

The great direct benefit to the farming industry is that here is a body wih a membership of researchers, teachers and commercial users, which holds meetings carefully spread over New Zealand. In many centres Grassland Association conferences are the only major scientific seminars to be held there. It is significant that support in the more rapidly developing isolated areas is greater than in the centres which are heavily serviced, such as Hamilton or Palmerston North, or where the pattern of farming is at the time particularly stable, such as was evidenced at the Master-ton and Hastings conferences. Support for conferences held in Alexandra, Greymouth, Te Kuiti and Invercargill, for example, has been strong.

By going to the different areas, the particular local problems and advantages are defined and discussed and activities of the Association are constantly being brought before new groups of farmers and farm services. In addition, locally based researchers are able to meet interested people on their home ground.

Most farmers, including the writer, first came in contact with the Association because it came to their local scene. We have met many people whose thoughts can help set our own thinking going in new or better directions. One can listen to papers and join in 
discussion; one has in the group many researchers and teachers covering a wide field of specialized knowledge and with the amount of social and field-day time provided can identify those with particular interests and discuss matters of mutual concern, to the great benefit of the commercial user, and we may reasonably hopc, to the benefit of the scientist who here meets the farmers most interested in improvment of technical aspects of their industry. No other organization known to me can provide this contact on common ground. The fact that the farming membership of the Association has recently increased greatly indicates many more are becoming aware of it and of its value.

For farmers unable to attend conference, the Proceedings provide the opportunity to keep in touch and extend their own thinking. Conference provides opportunity to listen, discuss and gain at first hand information which suffers some time lag when obtained through an extension worker.

I, and others like myself, find that as we develop ideas other farmers become interested, with a "stone in pond" effect and thus advances of very considerable extent come from the catalyst which is the Grassland Association. Looking at the writer's experience, through the latter 1960s as we increased utilization and reduced the fraction of self-rationing grasses such as Agrostis spp. and Holcus lanatus, we were becoming increasingly dissatisfied with the results of our grazing management, which was a sort of setstocking. We had acquired some knowledge of benefits of rotational grazing but nowhere was there available any ready-made knowledge of how to handle large mobs of sheep every one or two ' days, and what problems might be too serious. We had a great deal of helpful discussion with, and listened to and heard papers by, likely research workers. Over a long period many have helped us, and I would especially remember Sears, Brougham and Ball. Finally, in 1970 we took a chance on the risks, which proved to be fewer than we feared, and started rotating our sheep in groups of 2000 to 3000 over the winter on hill country, as one or two had started to try on easy land. It took a very short time for these practices to become commonplace and more polished.

\section{WHAT OF THE FUTURE?}

"One must always be prepared to justify to oneself what one does or believes, and anything which is to be done can always be done better." I submit that in this Association we have a large group of people who are active thinkers and who subscribe to my 
philosophy stated above; they also have an interest and a faith in grassland farming.

We are the only group with such a broad-spectrum membership - it is important that we continue to hold the interest of scientists as well as teachers and that they continue to welcome the commercial people (farmers and farm servicers) so this uniqus group can continue and develop.

More people coming into farming, either by inheritance or otherwise, nowadays have some technical education which is good, but we must remember that the many men starting without money who come into ownership via sharemilking or shearing, for example, can prove to be as capable farmers as anyone else. Consequently our group has a continuing duty to publicize itself, going around the country and thus assuring a regular intake of new members.

This is a democratic body and new ideas and developments can always come from the ordinary membership. However, those elected to office have a heavy responsibility to the Association and more so to the whole industry to select geographical areas where help and development are most timely. We need in our management a group who have a knowledge of what research is being undertaken, what developments are coming through the pipeline. They need to know what parts of current knowledge can presently be applied and particularly what can be further developed by the broad spectrum of scientific disciplines and the broad base of non-scientific members with differing specialized interests and abilities.

The Association can and must continue its activities and of course develop them. At present I believe that the greatest factor holding down pastoral production is a tremendous lack of grazing management coupled with a lack of intelligent fencing (this latter in respect of quantity, layout and cost). It may be that the Grassland Association could apply some type of group study over this field and might achieve, not just a spreading of present knowledge, but, from what is known, synthesize some improvements in practices, especially in the field of balancing costs to returns and in development of better and cheaper fences.

\section{CONCLUSIONS}

Finally, to recap my thoughts on the value of this body to pastoral farming. For a period of fifty years we have taken the scientists and teachers around the country to meet the farmers, so that in all areas the keener farmers are able to meet and hear them. We 
have also taken some farmers to meet other farmers. These have learned a great deal of technical knowldge faster than they would have by any other means and, more importantly, they have been helped to do much better original thinking and often experimentation. What they have learned and developed has spread around the rest of the farming community, to the benefit of the whole country. For the individual farmer this sort of thing makes his occupation a much more satisfying one and I firmly believe job satisfaction to be most important, as well as monetary return or remuneration. It is reasonable to assume that the scientists have gained from their contacts and that the teachers, both those in the institutions and those in extension, have been improved and encouraged in their work. 